\title{
Teaching as a collection development tool
}

\author{
By Carol Cronquist \\ Head of Technical Services \\ Ashland College
}

Collection development in the small academic library frequently suffers because of insufficient library personnel and faculty members who maintain taxing course loads. Frequently long periods of time pass when literally no one assesses just what is in the collection in any given area. Choice order cards are processed as the years pass by, and the collection frequently becomes misshapen because Choice is relied on as the sole tool for collection development.

The academic librarian with an additional subject master's degree who is also utilized as an instructor in an academic department on the small college campus ultimately can do much to fill this collection development gap.

As head of library technical services at Ashland College, a small liberal arts institution in Ohio with an enrollment of 3,956 students, I have had the opportunity to teach as an adjunct instructor in the English Department for the past five years. I have been teaching a required freshman English course which includes segments on the short story, the play, and poetry, and I have used a text favored by the majority of the department: X.J. Kennedy's Literature: An Introduction to Fiction, Poetry, and Drama, 4th edition. As with numerous other anthologies of this sort, a recent edition change reflected an effort on the part of the editor to include more contemporary literature by ethnic minorities, especially blacks, Hispanics and women. The library collection, which is undoubtedly typical of most small college libraries, could in no way support this change. Literally nothing was on our shelves by or about such authors as Kate Chopin, T. Coraghessan Boyle, Alice Walker, Alice Munro, Walter Van Tilburg Clark, Nagai Tatsuo, Toni Cade Bambara, or Gabriel Garcia Marquez. And given buying practices by a tradition-oriented faculty in English, it was likely that nothing would be added to the library collection to support either teaching or research in these areas.

In spare moments and with spare funds from the general book budget, I have been doing some sorely needed course-related collection development. I have located out-of-print books, imprints by foreign publishers, and other relevant titles that our vendor had not been able to supply.

In addition to this course-related form of collection development, I have developed a "casebook" of sorts that contains critical materials on the short stories in the Kennedy text. Ready access to the OCLC interlibrary loan system has made it possible for me to expeditiously collect materials for both my own use and other members of the English Department who are using the Kennedy text.

Though hired as a librarian with only adjunct status as an English instructor, my dual role in this institution has, I believe, had unanticipated benefits for both the English Department and the library.

\section{It's Computer Learning Month!}

October 1988 is Computer Learning Month, a public awareness campaign supported by 120 sponsors-including the computer and software industries, more than 40 United States and Canadian departments of education, the National Education Association, the American Federation of Teachers, and the National Parent Teachers Association.

A report published last spring by the $\mathrm{Na}$ tional Assessment of Educational Progress stated that "most students have used computers, like them, and have some familiarity with them, but their computer competence is generally low." A Nation at Risk, the 1983 report by the U.S. Department of Education, also recognized that "computers and computercontrolled equipment are penetrating every aspect of our lives." Computer Learning Month was created to help all segments of the population become comfortable with this new technology.

The objectives of this year's Computer Learning Month are: to increase the public awareness of how computers are used as tools at home, work, and school; to provide programs for schools, universities, community groups, user groups, and organizations to experience the benefits of technology; to stimulate the innovative use of computers; and to promote equal access to computer learning for everyone.

Computer Learning Month is a non-profit educational foundation and a subsidiary of the Software Publishers Association. For more information, contact: Computer Learning Month, P.O. Box 60007, Palo Alto, CA 943060007 . 